\title{
LCZ696, an angiotensin receptor neprilysin inhibitor (ARNI): clinical development in heart failure and hypertension
}

\author{
Martin P Lefkowitz
}

From 5th International Conference on cGMP: Generators, Effectors and Therapeutic Implications Halle, Germany. 24-26 June 2011

\section{Background}

Natriuretic peptides have potent natriuretic and vasodilator properties, reduce sympathetic drive, inhibit aldosterone secretion and have antiproliferative and antihypertrophic properties [1]. Increasing the concentration of natriuretic peptides through neprilysin (NEP) inhibition thus represents a therapeutic approach with the potential to confer cardiac, vascular and renal protection. Prior research, however, has suggested that the clinical benefits from NEP inhibition can be best leveraged if the renin-angiotensin-aldosterone system (RAAS) is simultaneously inhibited.

\section{Results}

LCZ696 is a first-in-class angiotensin receptor neprilysin inhibitor (ARNI) which provides concomitant inhibition of NEP and the angiotensin receptor. Ingestion of LCZ696 delivers systemic exposure to AHU377 (which is then rapidly metabolized to LBQ657, a specific NEP inhibitor) and to valsartan (an angiotensin II receptor blocker). LCZ696 treatment is associated with dosedependent increases in plasma cGMP, renin activity and angiotensin II, consistent with the drug's dual mechanism of action; a dose of 200-400 mg LCZ696 achieves approximately $90 \%$ of its maximal NEP inhibition [2].

In a large Phase 2 study in hypertensive patients $(\mathrm{n}=1328), \mathrm{LCZ696} 400 \mathrm{mg}$ and $200 \mathrm{mg}$ once daily reduced mean office systolic and diastolic blood pressure (BP) by an additional $6 / 3$ and $5 / 3 \mathrm{mmHg}$ compared with valsartan 320 and $160 \mathrm{mg}$, respectively (both $P<0.05)$; 24-hour ambulatory BP monitoring results were

Correspondence: marty.lefkowitz@novartis.com Cardiovascular Metabolism, Novartis Pharmaceuticals Corporation, East Hanover, NJ 10901, USA consistent with office BPs. Pulse pressure was also lowered to a greater extent with LCZ696 than the respective valsartan groups (both $P<0.05$ ) [3]. In chronic heart failure patients $(\mathrm{n}=27)$, after 3 weeks treatment, LCZ696 $200 \mathrm{mg}$ bid increased plasma cGMP levels while decreasing plasma NT-proBNP and plasma aldosterone levels (all $P<0.01$ ) as compared to baseline values (4). The Phase III PARADIGM-HF study is evaluating whether LCZ696 is superior to enalapril in delaying the time to cardiovascular mortality or first occurrence of heart failure (HF) hospitalization in patients with HF and reduced ejection fraction [4]. The Phase II PARAMOUNT study is evaluating LCZ696 for HF patients with preserved ejection fraction [5]. Both studies are ongoing.

\section{Conclusion}

Dual inhibition of neprilysin and the angiotensin receptor with LCZ696 may represent an attractive therapeutic approach for a range of cardiovascular diseases, including hypertension and heart failure, in which vasoconstriction, volume overload and neurohormonal activation play a part in pathophysiology.

Published: 1 August 2011

\section{References}

1. Pandey KN: Emerging roles of natriuretic peptides and their receptors in pathophysiology of hypertension and cardiovascular hypertension. J Am Soc Hypertens 2008, 2:210-226.

2. Gu J, Noe A, Chandra P, Al-Fayoumi S, Ligueros-Saylan M, Sarangapani R, Maahs S, Ksander G, Rigel DF, Jeng AY, Lin TH, Zheng W, Dole WP: Pharmacokinetics and pharmacodynamics of LCZ696, a novel dualacting angiotensin receptor-neprilysin inhibitor (ARNI). J Clin Pharmacol 2010, 50:401-414.

3. Ruilope LM, Dukat A, Bohm M, Lacourciere Y, Gong J, Lefkowitz MP: Bloodpressure reduction with LCZ696, a novel dual-acting inhibitor of the 
angiotensin II receptor and neprilysin: a randomised, double-blind placebo-controlled, active comparator study. Lancet 2010, 375:1255-1266.

4. Kobalava Z, Pavlikova E, Averkov O, Moiseev V, Albrecht D, Feng A, Priyamvada C, Jordaan PJ: First experience with concomitant AT1 and neprilysin inhibition with LCZ696 in patients with chronic heart failure. Circulation 2010, 122 (21 Suppl):19378.

5. [http://Clinicaltrials.gov], identifier NCT01035255.

6. [http://Clinicaltrials.gov], identifier NCT00887588.

doi:10.1186/1471-2210-11-S1-03

Cite this article as: Lefkowitz: LCZ696, an angiotensin receptor neprilysin inhibitor (ARNI): clinical development in heart failure and hypertension. BMC Pharmacology 2011 11(Suppl 1):O3.

Submit your next manuscript to BioMed Central and take full advantage of:

- Convenient online submission

- Thorough peer review

- No space constraints or color figure charges

- Immediate publication on acceptance

- Inclusion in PubMed, CAS, Scopus and Google Scholar

- Research which is freely available for redistribution

Submit your manuscript at www.biomedcentral.com/submit 